\title{
Role of Job Characteristics, Job Promotion and Disciplinary Work in Improving Employee Loyalty through Job Satisfaction in Department of Public Work in East Java Province
}

\author{
Mahmudah Enny W. \\ Department of Management, Economic Faculty \\ Bhayangkara University Indonesia.
}

\begin{abstract}
Department of Public Work (PU) in East Java Province as one of local government agencies that have a mandate to realize the management of water resources to achieve environmentally sound people's welfare, and ensure national unity and implemented equitably by relying on participation and community self-reliance. This making human resources as a major component in their duties because no matter how good the technology, if there are not good human resources, the technology will not be able to provide benefits. Therefore, to improve the quality of management attention is expected to pay attention to employee satisfaction climate creates loyalty that will work. This study aims to examine and analyze the effect of job characteristics, promotion and discipline in increasing employee loyalty through job satisfaction at the Department of Public Work in East Java Province. This study uses the independent variables are the characteristics of the job (X1), promotion (X2) and discipline (X3) and the dependent variable is job satisfaction (Y1) and employee loyalty (Y2). Model of the relationship between the variables studied the effect of job characteristics, promotion and discipline in increasing loyalty through satisfaction of employees working there. Characteristics of employment, promotion and discipline have a direct impact on employee loyalty and through job satisfaction. Based on the findings of this study can be used as a policy decision-making and increase the productivity of the employees that are specifically useful for the management of the Department of Public Work in East Java Province.
\end{abstract}

Keywords: Human Resource Management, Job Satisfaction, Employee Loyalty

\section{INTRODUCTION}

Human resource management is an activity that needs and has an ideal role within an organization. Its main focus is the people or employees. Without them there would be no requirements in the management of other resources. Because human resources activities involving people as an employee, then the employee is one of the most dominant element in the strategic and business goals. Thus, in an organization of these activities need to be planned and managed effectively and efficiently in order to achieve the objectives and results as desired. Employees is an important factor for the organization, in addition to other factors such as production material, capital, market, or the use of new technology machines. This is because man is a planner, actors and determinants of the realization of the needs and objectives of the company. Thus organizations need employees who are skilled, proficient, morale and dedicated high in completing the work in accordance with the business organization. 
Department of Public Work (PU) in East Java Province is one of the government agencies engaged in community empowerment. Organization Department of Public Work in East Java Province Regional Regulation No. 9 of 2008 (Article 1) on the Organization and Work Procedure of the Regional Office of East Java Province, which is a follow up in implementation of Government Regulation No. 41 of 2007 concerning the regional Organization , In order to achieve and carry out the duties and responsibilities of the organization as a government regulation in question, the necessary human resources are skilled and competent in their respective fields.

Human resource management (HRM) is not something new in the environment of an organization, improving the quality of human resources and limited there will continue to be a serious concern and refined to achieve things that idealized an organization or a company. Each company expects all employees can work well and have high morale, so what is the company's overall goals will be more easily achieved. Activities of the organization will be easily fulfilled if an employee has a high employment loyalty. With the loyalty of high employment, the employee will be more easily motivated to work well while creating job satisfaction for employees.

One way to improve the management of employee job satisfaction or employee is to put the work in accordance with the characteristics of the personal characteristics of employees. This is similar to what is said by Gunastri (2009: 14) is as follows: "the nature and tasks that include responsibility, kinds of tasks and the level of satisfaction derived from the work itself. Works that are intrinsically rewarding to be more motivating for most people and the unsatisfactory work ". With optimal job satisfaction an employee or an employee will always be free and happy in performing their duties and responsibilities assigned.

Thus one way to increase job satisfaction is to consider the characteristics of the work and responsibility. Working in an organization to earn rewards based on the belief that by working in an organization that someone will be able to satisfy all their needs. (Siagian, 2000). This is supported by research Jatmiko (2011) and Nice, concluded that the job characteristics and significant positive effect on job satisfaction.

Department of Public Work (PU) in East Java Province has a vision Realization of water resource management to achieve environmental welfare of the people, and to ensure national unity and implemented equitably by relying on participation and community self-reliance. To realize this vision for official agencies required the efforts of how to place workers with the field and the characteristics of each employee, because if someone will be able to enjoy them when they work in accordance with what is fun. With pleasure will cause satisfaction and loyalty at work. Loyal employees will continue working on their tasks and responsibilities well, because without coercion and will bring creative ideas.

But the suitability of job characteristics is still cause dissatisfaction on several employees, since not all employees are in accordance with the work that they do. It fosters demotivating for some employees which then led to the reduction in employee satisfaction. One of the things related to employee job satisfaction is a promotion that will eventually culminate in compensation grade.

Opportunities for promotion or career development is employee motivation is also needed by the employee. According Rival and Sagala (2009) career development is the process of improving the ability of individual work achieved in order to achieve the desired career. It can 
be concluded that career development is a continuous process through which individuals through personal efforts in order to realize the goal of career planning adapted to the conditions of the organization. According to Wahyudi (2002), career training necessary to understand the two processes, namely how people plan and implement their own career goals (career planing) and how institutions to design and implement a career development program (career management). Dessler (1997) argues that individual's career as a clerk will give you the advantage that satisfaction, personal development and life promotion to a position or a higher position, but an encouragement or motivation to move forward and develop the work.

Research Tambunan (2012), Minarsih (2007) and Nice (2011) which states that the variable promotions and significant positive effect on job satisfaction. Likewise with research Mariami (2013) which states that the variables that most influence on employee job satisfaction is variable career development in this regard is promotion.

Attitude towards work is an important aspect of every human aspiration. Factor this work can be an indicator of the accuracy of the aspirations of the attitude of the personnel of an organization as the impact of various policy approaches organizers. Attitude including an employee feelings and aspirations of the various dimensions of the work is often termed the "Job Satisfaction"

Human resources have an important role to make this happen. Hasibuan (2000) argues that human beings have always played an active role in every activity of the organization is as planners, actors and determinants of the realization of objectives of the organization, thus making man an asset that should be improved efficiency and productivity. On the other hand, the employee is not productive means employees do not have the morale high, not as resilient in the work and morale is low, the organization will not be able to run well.

Companies may believe that income, wages or salary are the main factors that influence employee satisfaction, so when the company was already providing sufficient salary, he felt that the employees were satisfied. Actually, employee satisfaction is not absolutely influenced by salary alone. Many factors affect the job satisfaction of employees, including the suitability of work, organizational policies including opportunities to develop, the working environment and the behavior of superiors.

New employees typically have a higher level of satisfaction than the old employee. This is because the new employees get more attention from the leadership. More attention is because as a new employee, of course management will explain their responsibilities and duties. Thus established communication between supervisors and subordinates. This makes them feel cared for and eager to work. Even the few new employees who get some training to support its work in the early tenure. Meanwhile, long-time employee who has worked within a certain time, will feel the saturation. Moreover, if during their work has not been moved to another section / has not been promoted. They wanted a change and a new challenge in his job. This challenge covers both in terms of amount of responsibility or perhaps the type of work. When companies do not give them a chance to develop, it will make them lazy to work and productivity drops.

The task for the management to employee morale and high moral standing and tenacious work. Usually employees are satisfied with what they get from the company will give more than what is expected and it will continue to strive to improve their performance, otherwise employee work satisfaction lower tend to see work as being dull and boring, so he works with 
forced and perfunctory, For it is imperative for organizations to identify any factors that make employees satisfied with the company / institution.

Factors affecting job satisfaction of employees, including the award / reward, a chance to grow / promotion, supportive work environment, salary and behavior of your boss / supervisor. According to Robbins (2002) in Cholil and Riani (2003) job satisfaction is employee attitudes toward work. Robbin also reminded to each maintainer organization to really look at the importance of understanding and fulfillment of work that has an impact on the productivity levels of absenteeism and labor turnover.

Department of Public Work (PU) in East Java Province has a system of career development (promotion) is certain, which is expected to make employees motivated to do career planning. However, not all employees of the Department of Public Work (PU) in East Java Province, motivated by career development system is because in order to achieve higher career, it takes the results of performance evaluation by superiors. Concerns emerged that the boss was not impartial in its assessment that enabled employees who excel compete with lower- performing employees. In fact, if an employee who excel can have a better career, it will lead to another employee job satisfaction and job loyalty was reached.

To get the job satisfaction among the factors that become the benchmark of the employee or the employee is the placement office. To get a good performance effort and maximum work. Work performance and maximum results can be reached with high discipline anyway. In this study, the authors decided to conduct a study of the organization or government agency that uses a lot of labor. Therefore, employees in this case is an important key in the process of development of the company is required to improve its performance.

The attitude and behavior of employees in the workplace is a major factor affecting the performance and growth of any organization in establishing cooperative relations of the company, especially in the less effective employees, and enforce discipline.

So it is necessary to improve work discipline and motivation to employees. In addition to matters relating to work discipline and motivation are the problems that must be seen further is a matter of ability (skill) the employees themselves, although there are stringent rules that created the organization or company to enforce in the discipline of work and a good motivation from superiors , but it needs the support of the employees, the performance of the organization in general and the goals of the organization in charge of companies or organizations will be achieved to the fullest.

\section{Human Resource Management}

\section{LITERATURE REVIEW}

Definition of management and human resources can be said that human resource management is a management science applied in human resource management issues. The writer saw a lot of definitions of human resource management, no one else is universal definition that can be accepted by all parties. Nonetheless, the author tries to present definitions of some experts who then drawn a conclusion of their opinions.

Dessler (2004: 2), define the human resource management "process acquire, train, assess, and provide compensation to employees, pay attention to their labor relations, health and safety, as well as a matter of justice". 
According to Flippo quoted Handoko (2011: 3), "Human resources management is the planning, organizing, directing and monitoring the activities of procurement, development, remuneration, integration, maintenance and disposal of human resources in order to achieve various goals of individuals, organizations and society ".

According Mangkunagara (2005: 2), namely: "HR Management is a planning, organizing, coordinating, implementing, and monitoring of procurement, development, provision of remuneration, integration, maintenance, and the division of labor in order to achieve the company's goals".

Based on these definitions can be interpreted that the human resource management can be defined as a process of planning, organizing, directing, monitoring than the procurement, development, compensation administration, integration, maintenance, and termination of employment with the intent to assist managers in achieving corporate goals. In accordance with the understanding of human resource management that has been formulated above, the activities of human resource management in an organization can be classified into several functions. As an applied science of management science, management of human resources management functions with application in the field of human resources. Wahyudi (2002: 12) mentions that the basic functions of the science of management with the implementation of the organization's human resources are as follows:

a) The planning function, which perform tasks in the procurement requirements planning, development, and maintenance of human resources.

b) Organizing function, which is preparing an organization by designing the structure and relationships between tasks that must be done by manpower prepared.

c) Executive functioning, which gives a boost willingness remedy creates work is carried out effectively and efficiently.

d) Control functions, which make measurements between the activities carried out by the standards that have been set, particularly in the field of labor.

Besides the basic functions, human resource management has several operational functions. Where essentially the operational functions of human resource management can be classified into three operational functions as revealed by Wahyudi (2002: 14), that the procurement, development and maintenance of Human Resources.

Operational functions of human resource management within the scope of the procurement of human resources and the development of human resources are directed to ensure the basic requirements of work ability. While the operational functions of human resource management within the scope of the maintenance of human resources are directed to ensure the basic requirements of work ability.

\section{Work Loyalty}

In carrying out the activities of employees will not be separated from the loyalty and work ethic, so that the employee will always perform their jobs well. Employees feel a profound pleasure to work being done

Hasibuan (2001), suggests that labor loyalty or allegiance is one element that is used in the assessment of employees that includes loyalty to his job, his position and the organization. This loyalty is reflected by the willingness of employees to maintain and defend the organization inside and outside the work of undermining the irresponsible people. 
The loyalty of the employees in an organization that is absolutely necessary for the sake of organization itself. According to Reichheld, the higher the loyalty of the employees in an organization, the easier it is for the organization to achieve organizational objectives predetermined by the owner organization (Utomo, 2002: 9). As for the opposite, for organizations lower the loyalty of its employees, it is increasingly difficult for the organization to achieve the goals of the organization that has been previously set by the owners of the organization. Loyalty work would be created if employees feel fulfilled in meeting the needs of the job, so that they feel at home working in a company. Yuliandri (in Kadarwati, 2003) confirms that the factors affecting employee loyalty is their working facilities, a review of welfare, working conditions and wages received from the company.

Furthermore, Steers and Porter (in Kusumo, 2006) states that the incidence of workplace loyalty is influenced by four factors, namely:

a) Personal characteristics, including age, years of service, gender, level of education, achievements of, races and several personality traits.

b) Job characteristics, such as the challenges of work, job stress, social interaction opportunities, job enrichment, identification of tasks, task feedback and matches task.

c) Characteristic design company, concerning the company's internal it can be seen from decentralization, formalization level, the level of participation in decision-making, at least have shown varying degrees of association with corporate responsibility, functional dependency and control functions of the company.

d) Experience gained in the work, including a positive attitude toward the company, confidence in a positive attitude toward the company, a sense of security.

Based on the factors that have been disclosed above can be seen that each of these factors have their own impact the viability of the company, so that the demands of loyalty expected by the company can only be fulfilled if the employee has the characteristics as expected and the company itself has been able to meet expectations employees, so it can be concluded that the factors that influence loyalty include: the facilities work, welfare benefits, working atmosphere wages received, personal characteristics of the individual or employee, job characteristics, the characteristics of the design company and the experience gained during the employee to pursue the job.

\section{JOB SATISFACTION}

In organizational life, job satisfaction is usually used as the basic measure of the degree of maturity of the organization. One of the symptoms that result in poor working conditions of an organization is the low job satisfaction, high job satisfaction otherwise is an indication of managerial effectiveness, which means that the organization has been managed well.

Job satisfaction according to Robbins (2001: 147) is defined as a person's general attitude towards work, the difference between the amount of reward received by workers and the number that they believe should be accepted. Because a belief in the self-satisfied workers are more productive (achievement) when compared with unsatisfied. This means that workers who are satisfied will demonstrate higher performance.

Job satisfaction according to Mathis and Jackson (2002: 98) is a positive emotional state of a person's work experience evaluated. Job dissatisfaction arise when these expectations are not met. Job satisfaction comprises many dimensions. In general, the observed phase is job satisfaction in the work itself, salary, recognition, relationships between supervisors with 
labor, and the opportunity to move forward. Job satisfaction is a measure of sustainable human development process in an organization. Therefore, no one manager can expect to be able to make all employees are happy in their work, job satisfaction should still get attention. With satisfying the various wants, wishes and needs of the employees will be able to determine their attitudes and behaviors in the work. From the above it can be concluded that satisfaction is an emotional state that is pleasant or unpleasant is felt by an employee of looking at their work.

\section{JOB SATISFACTION MEASUREMENT INDICATORS}

Job satisfaction is a research or reflection and feelings of workers to work. This is evident in the positive attitude of workers to the job at hand and the environment. Conversely, a disgruntled employee will act negatively toward work and form different from one another. Employee dissatisfaction should be detected by the company. According Muchinsky (1997: $424)$, the variables that can be used as an indication of declining job satisfaction is absenteeism, turnover, and job performance.

As'ad (2004: 103) explains that the variables that can be used as an indication of declining job satisfaction is the high rate of absenteeism (absenteeism), high employee turnover (turnover), decreasing. Labor productivity or employee performance (performance). If the indication of the decline in employee satisfaction rise to the surface, it should be addressed so as not to hurt the company.

To know the indicators that influence job satisfaction, according Luthans (2005) and consists of five indicators, namely:

1. Compensation or payment.

Compensation such as salaries and wages, incentive allowances, and facilities received by employees. Employees want a system of wages and compensation policies that are perceived as fair, no doubt, and in line with his hopes. When wages are seen as fair based on the demands of work, the level of individual skills and community wage standards are likely to be generated satisfaction.

2. The job itself.

Employees tend to prefer jobs that provide opportunities to use abilities and skills, according to the education, and has full authority. These characteristics make the work more challenging. Less demanding jobs create boredom, but too much challenge can also create frustration and a feeling of failure.

3. Co-workers.

For most employees work also fills the need for social interaction. Therefore, having coworkers were friendly and support ushered into increased job satisfaction. Besides coworkers who can be invited to work equal, communicate well, and encourage each other can also increase job satisfaction.

4. Promotion of work.

Sale occurs when an employee moves and a job to another position higher salaries, responsibilities and organizational levels. At the time of promoted employees generally face increased demands and expertise, capabilities and responsibilities. Most employees feel positive because it promoted. Sale allows the company to leverage the capabilities and skills of employees as high as possible. Effective promotion system allows an organization to match sustainable demand be a competent workforce with employees' desire to apply the skills that have been mastered.

5. Supervision / control.

Supervision has an important role in management. Supervision of employees directly related to and affected employees in doing his job. Employees generally prefer to have 
the supervision of a fair, open and willing to cooperate with subordinates. Supervision also choose the right person for a job, create interest each person to work and teach how to do its job, measure and assess the results of its work, holding corrections when necessary and move people to work more suitable or dismiss them which turned out to not be able to work better, give praise and appreciation for good work, and eventually align everyone to working atmosphere equal closely with other friends co-workers, all of it is done in a fair, patient, and tolerance so that everyone do his job with proficient, conscientious, intelligent, passionate, and perfect.

\section{HYPOTHESIS}

Based on the background, and a literature review of previous studies that showed that it requires a theory of the characteristics of employment, promotion, work discipline, job satisfaction, and employee loyalty. These theories need to be studied because it will help the process of analysis. In the process of analysis involves thinking associated with a theory that can be expressed with the universal theory required for all specific cases and special, therefore the process of thinking embodied in a theoretical study contains the thought process of deductive means the researchers will analyze and answer the problems and draw conclusions by or starts from the things that are common toward the things that are special. So that in a study, the researchers do not think any deductive or inductive thinking, but the interaction back and forth from deductive reasoning process (theoretical studies) and inductive thinking process (empirical studies). At the time of such a process is found both variables in studies with a theoretical as well as empirical studies and causality relations on the basis of the hypothesis of the study was composed.

Based on an explanation and background of the above, then drafted a conceptual framework of the research presented Figure 1.

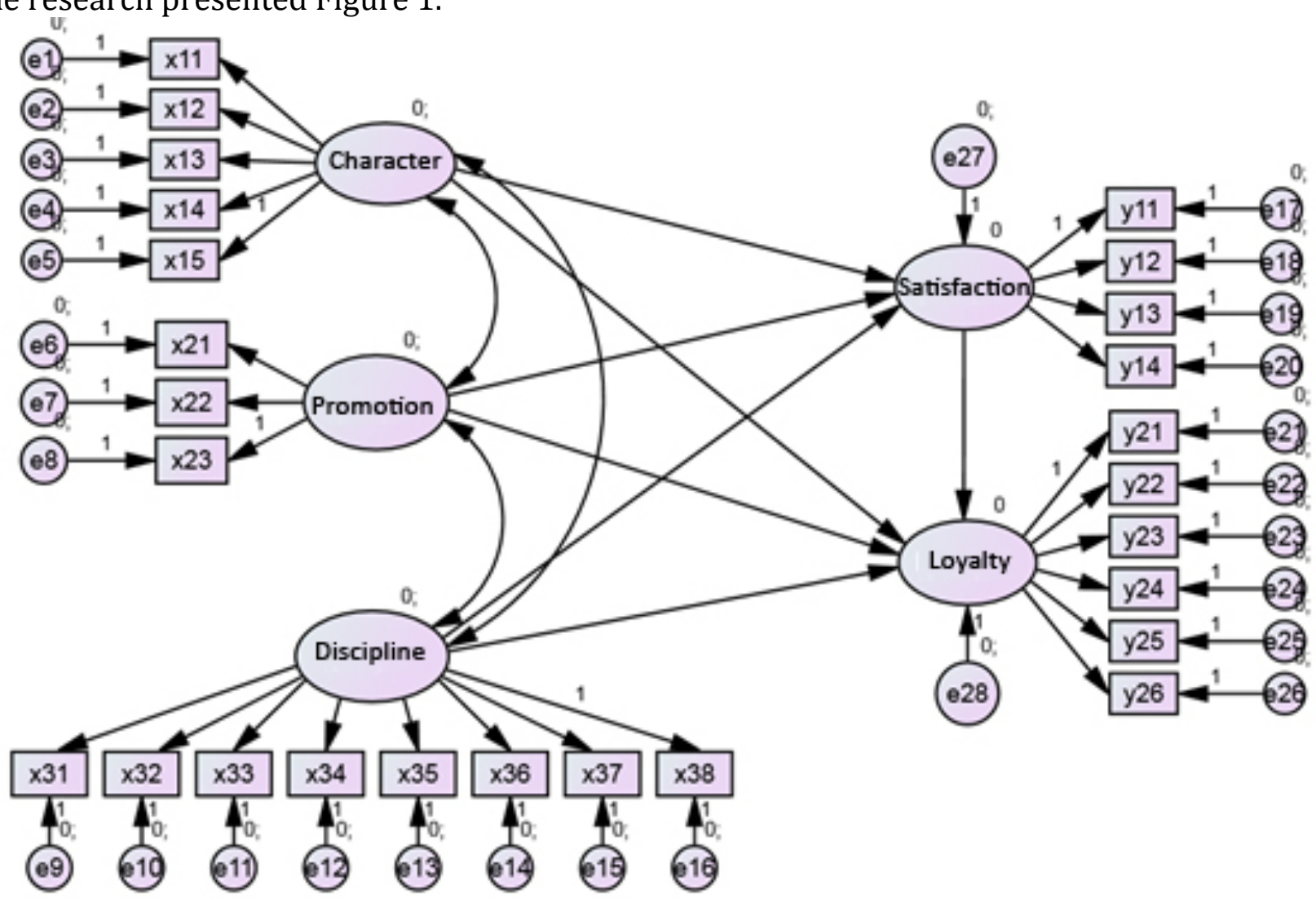

Figure 1. Conceptual Framework Research 
The hypothesis is provisional estimates of a problem that must be substantiated. Based on the background, problem formulation, research objectives and review of the literature that has been stated previously, then that becomes the hypothesis in this study are:

1. Job characteristics significantly influence job satisfaction of employees at the Department of Public Works Irrigation East Java Province.

2. Promotions significant effect on job satisfaction of employees at the Department of Public Works Irrigation East Java Province.

3. Discipline significant effect on job satisfaction of employees at the Department of Public Works Irrigation East Java Province.

4. Job characteristics significantly influence employee loyalty at the Department of Public Works Irrigation East Java Province.

5. Promotions significant effect on the loyalty of employees at the Department of Public Works Irrigation East Java Province.

6. Discipline significant effect on the loyalty of employees at the Department of Public Works Irrigation East Java Province.

7. employee satisfaction significantly influence employee loyalty at the Department of Public Works Irrigation East Java Province

\section{Types of Research}

\section{RESEARCH METHOD}

According Sugiyono (2013), the study called conclusive research because it aims to test hypotheses about the relationship between the variables studied, where the necessary information is clearly defined, the research process of formal and structured, using a relatively large sample and representative, and data analysis using techniques qualitative.

Based on the opinion and Efendy Singarimbun (2000), this study also called survey is a study conducted by taking a sample of the population and the questionnaire as a data collection tool staple. Survey research can also mean a study could be done on a small or large populations, but the data studied are data from a sample taken from the population, so that the relative incidence was found, the relationship between variables is socialist or psychological.

\section{Population of Research}

Population is a generalization region consisting of objects or subjects that have quality and characteristics defined in the study to learn and then drawn conclusions (Sugiyono, 2013). The study population was staff and employees and employees other than the production of the Public Works Department in East Java Province which numbered 170 employees.

\section{Samples of Research}

The sample is part of the population that has the same characteristics as the population. The sampling technique in this study using probability sampling technique, which is a sampling technique that provides equal opportunity for each element (member) of the population to be selected as members of the sample. This probability sampling technique was different is simple random sampling, proportionate stratified random sampling, disproportionate stratified random sampling area (cluster) sampling (Sugiyono, 2010: 120). The sample is representative of the majority or the population to be studied (Suharsimi Arikunto, 2010: 109). Of the study population as many as 170 employees in the Public Works Department of Irrigation of East Java Province, then respondents drawn in this study is the number of 175 respondents, so in this study using population studies or studies census, as submitted by Suharsimi Arikunto (2010: 173) "if someone wants to examine all the elements that exist in the area of research, 
the research was population research, study or research is also called the study or the study population census".

\section{Variable Classification}

The variables that will be examined in this study and classified into two general categories:

Independent variables or exogenous variables is the variable whose value affects the value of other variables, given the symbol $\mathrm{X}$ is:

1. Job Characteristics (X1)

2. Promotion of Position (X2)

3. Discipline (X3)

The dependent variable or variables endogenous, ie variable whose value depends on the value of other variables, given the symbol $Y$ in this study are:

1. Job Satisfaction (Y1)

2. Employee Loyalty (Y2)

Measurements for each variable research is conducted in the form of scoring according to Likert scale. Likert scale is a psychometric scale commonly used in the questionnaire, and is the most widely used scale in the form of survey research. The name is taken from the scale of Likert Rensis name, which published a report describing its use. Likert scale (Likert Scale) is a method that measures attitudes to agree or all disagree the subject, object, or certain events, described in the statements contained in the questionnaire. Likert Scale in this study using a 5 point rating where the number 1 indicates the lowest value and the numerical value 5 indicates the highest value.

Questionnaire design built to allow investigators in describing the variables and indicators in the form of items, which will be used as the material preparation of the questionnaire, shown in Table 1.

TABEL 1: Questionnaires Design

\begin{tabular}{|c|c|c|c|}
\hline $\begin{array}{c}\text { Theoretical } \\
\text { Concept }\end{array}$ & Variable & Indicator & Item \\
\hline Job Satisfaction & $\begin{array}{l}\text { Job } \\
\text { Satisfaction } \\
\text { (Y1) }\end{array}$ & $\begin{array}{l}\text { 1. Employment challenging } \\
\text { 2. Salary fair } \\
\text { 3. Working conditions that favor } \\
\text { 4. Support from colleagues }\end{array}$ & $\begin{array}{l}\mathrm{Y} 1.1 \\
\mathrm{Y} 1.2 \\
\mathrm{Y} 1.3 \\
\mathrm{Y} 1.4\end{array}$ \\
\hline Work Loyalty & $\begin{array}{l}\text { Works } \\
\text { Employee } \\
\text { Loyalty }\end{array}$ & $\begin{array}{l}\text { 1. Obey the rules } \\
\text { 2. Responsibility of Companies } \\
\text { 3. Willingness to cooperate } \\
\text { 4. Sense of belonging } \\
\text { 5. Relations between people } \\
\text { 6. Passions to work }\end{array}$ & $\begin{array}{l}\text { Y } 2.1 \\
\text { Y2.2 } \\
\text { Y2.3 } \\
\text { Y2.4 } \\
\text { Y2.5 } \\
\text { Y2.6 }\end{array}$ \\
\hline $\begin{array}{l}\text { Job } \\
\text { Characteristic }\end{array}$ & $\begin{array}{l}\text { Job } \\
\text { Characteristic }\end{array}$ & $\begin{array}{l}\text { 1. Autonomy } \\
\text { 2. Variation jobs } \\
\text { 3. Identity Task } \\
\text { 4. Significance task } \\
\text { 5. Feedback }\end{array}$ & $\begin{array}{l}\mathrm{X} 1.1 \\
\mathrm{X} 1.2 \\
\mathrm{X} 1.3 \\
\mathrm{X} 1.4 \\
\mathrm{X} 1.5\end{array}$ \\
\hline
\end{tabular}




\begin{tabular}{|c|c|c|c|}
\hline $\begin{array}{c}\text { Theoretical } \\
\text { Concept }\end{array}$ & Variable & Indicator & Item \\
\hline Job Promotion & $\begin{array}{l}\text { Job } \\
\text { Promotion }\end{array}$ & $\begin{array}{l}\text { 1. Experience (seniority) } \\
\text { 2. Skills (skills) } \\
\text { 3. The combination of experience and skills }\end{array}$ & $\begin{array}{l}\mathrm{X} 2.1 \\
\mathrm{X} 2.2 \\
\mathrm{X} 2.3\end{array}$ \\
\hline Discipline & $\begin{array}{l}\text { Discipline } \\
\text { (X2) }\end{array}$ & $\begin{array}{l}\text { 1. Purpose and Capabilities } \\
\text { 2. Exemplary Leadership } \\
\text { 3. Reply Services } \\
\text { 4. Justice } \\
\text { 5. Waskat } \\
\text { 6. Penalties Penalties } \\
\text { 7. Assertiveness } \\
\text { 8. Relations humanity }\end{array}$ & $\begin{array}{l}\mathrm{X} 3.1 \\
\mathrm{X} 3.2 \\
\mathrm{X} .3 \\
\mathrm{X} 3.4 \\
\mathrm{X} 3.5 \\
\mathrm{X} 3.6 \\
\mathrm{X} 3.7 \\
\mathrm{X} 3.8\end{array}$ \\
\hline
\end{tabular}

Source: Researcher (2015)

\section{LIMITATIONS AND RESEARCH ASSUMPTIONS}

The study was limited to the study of the characteristics of employment, promotion, discipline, job satisfaction, and employee loyalty, by taking the research object Public Works Department employee Irrigation East Java Province. This research is aimed to test the hypothesis to explain the relationship or influence the characteristics of employment, promotion and discipline on job satisfaction and employee loyalty Public Works Department of Irrigation of East Java Province. The assumption of this study is the independent variable other than the characteristics of employment, promotion and discipline carry no (small) on the satisfaction and loyalty of employees.

Data used in this study was twofold primary data and secondary data.

1. Primary data is data collected directly from the research is the answer of the respondents on matters relating to the characteristics of the work, discipline, job satisfaction, and employee loyalty Public Works Department of Irrigation of East Java Province.

2. Secondary data is data obtained from the company (Public Works Department of Irrigation East Java Province), which became the object of research related to the records and operations of the company.

Data collection procedures were performed with the following steps:

1. The initial survey, conducted as an initial observation of the condition of the company that became the object of study and explore issues that exist in order to obtain data related to research and as a basis for the preparation of the questionnaire.

2. The interview, conducted by conducting interviews to speakers from organizations or companies concerned as well as explore the necessary information in the study.

3. Distribution of the questionnaire, was conducted to obtain data on respondents' ratings of job characteristics variables, promotion and discipline, job satisfaction, and employee loyalty Public Works Department of Irrigation of East Java Province.

\section{DATA ANALYSIS TECHNIQUE}

Inferential statistical analysis focuses on the field of study analysis and interpretation of data to draw conclusions. This analysis is used to test the hypothesis of the research that has been set by using sample data obtained. Statitik inferential methods used in the analysis of this research is Structural Equation Modeling (SEM). Reasons for using SEM, the consideration that the causal relationship is defined in this study using a simple model that does not play double roles as employee satisfaction. Forms causal relationship like this requires analysis that is able to explain simultaneously on the relationship so the methods used in this study using SEM. 
The use of SEM as a tool of analysis based on the grounds complexity model used, the limitations of multidimensional analysis tools that are often used in quantitative research, such as multiple regression, factor analysis, descriminant analysis and others. The weakness of this analysis tool can only analyze one relationship at a time. In the language of the study stated that the analysis techniques can only test one dependent variable through several independent variables. In fact, the company faced a situation where there is more than one dependent variable that must be linked to an unknown degree interrelasinya (Ferdinand, 2002: 26). SEM as an extension or a combination of multivariate techniques.

Structural Equation Modeling (SEM) is a statistical tool used to resolve simultaneous multilevel models that can not be solved by the linear regression equation. SEM can also be considered as a combination of regression and factor analysis. SEM can be used to solve the model equations with more than one dependent variable and the reciprocal influences (recursive). SEM based on the analysis of the matrix covariance thus providing more accurate than the linear regression analysis. Statistics programs that can be used to complete the example SEM Analysis of Moment Structure (AMOS) or LISREL.

The data obtained and used as a sample of respondents who study through questionnaires distributed, will be analyzed using Structural Equation Modeling (SEM) by AMOS 22 and 22. SPSS AMOS program shows the measurements of the structural problems, and are used to test the hypothesized model. This is due to their ability to estimate the unknown coefficients of the linear equation structural model that accommodates the latent variables, measurement error accommodate the dependent and independent variables, warning accommodate simultaneous reciprocity and interdependence.

Structural Equation Modeling has the main characteristics that distinguish it from other multivariate analysis techniques. In SEM estimates are double dependency relationship (multiple dependence relationship). SEM also allowed to represent concepts that previously were not observed (unobserved concept) in an existing relationship and taking into account the measurement error.

\section{Validity Data Test}

Validity test used to determine whether the indicators as a measure of the concept can measure that should be measured, according to Anderson \& Girbing and Ferdinand (2000: 187) states that each indicator has a Critical Ratio is two times larger than the standard error, the indicator is valid measure what should be measured. In the model presented Critical Ratio values (which is identical to the $t$ the regression) can be obtained via the AMOS program (Analysis of Moment Structure).

\section{Reliability Data Test}

Reliability test is used to determine the extent of the contribution of indicators as a constituent of the concept or construct, reliability is calculated via the instrument used reliability index of SEM models analyzed by the formula:

$$
\text { Construct Reliability }=\frac{(\Sigma S \tan \text { dard Loading })^{2}}{(\Sigma S \tan \text { dard Loading })^{2}+\Sigma \varepsilon j}
$$

Standard Loading obtained directly from the standardized loading for each indicator (taken from computer calculations AMOS), the lambda value obtained from each indicator. $\varepsilon j$ is the 
measurement error of each indicator. Measurement indicator is equal to 1-reliability indicators of rank two of the standardized loading every indicator analyzed. The limit values are used to assess an acceptable level of reliability is 0.70 , although the size is not the number of "dead" means that if the research is explanatory, the value below 0.70 is still acceptable as long as accompanied by the reasons empirical look in the process explanatory.

Ferdinand (2000: 311) provides a good guideline for interpreting reliability index. Then states that the explanatory research, the reliability of which were between 0.5 to 0.6 is enough to justify a study. Thus the analysis of the data that is being used in this study provides results that can be interpreted as quite reliable.

\section{Effect of Variable Delivery Research}

\section{RESULT AND DISCUSSION}

Structural equation with many variables and paths between variables there are significant among variables that include direct effect, indirect effect, and total effect. For it is discussed as follows:

\section{Direct Influence between Research Variables}

Direct relationships occur between the exogenous variables (characteristics of the job, a promotion and discipline) with the endogenous variables (job satisfaction) as intervening variables and endogenous variables (employment loyalty). This relationship through a study, to see whether there is a direct relationship between these variables. The result of a direct link is a direct connection that occurs between exogenous and endogenous variables. In detail or detail through studies in this study, the direct connection (direct), it has been described in Table 2 below:

Tabel 2: Direct Influence between Research Variable

\begin{tabular}{|c|l|c|c|}
\hline \multicolumn{2}{|c|}{ DIRECT INFLUENCE } & \multicolumn{2}{c|}{ endogenous variables } \\
\cline { 3 - 4 } & Job Satisfaction & Job Loyalty \\
\hline \multirow{3}{*}{$\begin{array}{c}\text { Exogenous } \\
\text { Variables }\end{array}$} & Job Characteristic & 0,250 & 0,216 \\
\cline { 2 - 4 } & Job Promotion & 0,317 & 0,180 \\
\cline { 2 - 4 } & Job Discipline & 0,125 & 0,137 \\
\cline { 2 - 4 } & Job Satisfaction & 0,000 & 0,439 \\
\hline
\end{tabular}

Source: Researcher (2015)

From table 2, can be explained much influence directly of exogenous variables on endogenous variables. Promotions provides most direct effect on job satisfaction compared to both other variables. Furthermore, job satisfaction provides the greatest effect on employee loyalty.

\section{Indirect Influence between Research Variables}

Indirect relationships occur between the exogenous variables (characteristics of the job, a promotion and discipline) with the endogenous variables (job satisfaction) as intervening variables and endogenous variables (employment loyalty). This is indirectly there is a relationship between these variables.

The results of indirect relationships (indirect) is an indirect relationship that occurs between variables - exogenous and endogenous. In detail through the studies in this study, the correlation is not direct (indirect) between these variables and are described in Table 3 below.

Based on Table 3 above, may explain the magnitude of the indirect effect (indirect effect) exogenous variables on endogenous variables. Promotion gives biggest indirect effect on 
W, M. E. (2016). Role of Job Characteristics, Job Promotion and Disciplinary Work in Improving Employee Loyalty Through Job Satisfaction in Department of Public Work in East Java Province. Archives of Business Research, 4(2), 01-19.

employee loyalty variables and variables in second place is the variable characteristics of labor work.

Table 3: Indirect Influence between Research Variables

\begin{tabular}{|c|l|c|c|}
\hline \multicolumn{2}{|c|}{ INDIRECT INFLUENCE } & \multicolumn{2}{c|}{ endogenous variables } \\
\cline { 3 - 4 } & Job Satisfaction & Job Loyalty \\
\hline \multirow{3}{*}{$\begin{array}{c}\text { Exogenous } \\
\text { Variables }\end{array}$} & Job Characteristic & 0,000 & 0,110 \\
\cline { 2 - 4 } & Job Promotion & 0,000 & 0,139 \\
\cline { 2 - 4 } & Job Discipline & 0,000 & 0,055 \\
\cline { 2 - 4 } & Job Satisfaction & 0,000 & 0,000 \\
\hline
\end{tabular}

Source: Researcher (2015)

\section{Total Inter Variables Influence}

The total influence is the sum effect directly and indirectly between the exogenous variables (characteristics of the job, a promotion and discipline) with the endogenous variables (job satisfaction) as intervening variables and endogenous variables (employment loyalty). This relationship through a study, to see whether directly or indirectly on the relationship between these variables. The results of the relationship directly and indirectly that occurred between variables - exogenous and endogenous variables in this study, it will be explained in detail in Table 4 below:

Table 4: Total Inter Variables Influence

\begin{tabular}{|c|c|c|c|}
\hline \multirow{2}{*}{\multicolumn{2}{|c|}{ Total Influence }} & \multicolumn{2}{|c|}{ endogenous variables } \\
\hline & & Job Satisfaction & Job Satisfaction \\
\hline \multirow{4}{*}{$\begin{array}{c}\text { Exogenous } \\
\text { Variables }\end{array}$} & Job Characteristic & 0,250 & 0,325 \\
\hline & Job Promotion & 0,317 & 0,319 \\
\hline & Job Discipline & 0,125 & 0,137 \\
\hline & Job Satisfaction & 0,000 & 0,439 \\
\hline
\end{tabular}

Source: Researcher (2015)

Based on Table 4 above, the magnitude of the total effect of exogenous variables on endogenous, ie job characteristics have the greatest influence on employment loyalty and promotions have the most impact on job satisfaction. Job satisfaction is a significant impact on employment loyalty variable.

\section{DISCUSSION}

Characteristics of the work (X1) which is implemented by the Public Works Department in East Java Province has a positive and significant impact on job satisfaction (Y1). This means that the characteristics of the work in this respect autonomy, variety of work, task identity, task significance and feedback is applied by the Public Works Department in East Java Province in accordance with the wishes and expectations of employees of the Public Works Department of Irrigation of East Java Province. The level of job characteristics largely determine the suitability of employee satisfaction. The results of the research fully supports the results of research conducted by Jatmiko (2011) and Nice (2011) which says that the job characteristics and significant positive effect on job satisfaction. The results of this study also supports the theory put forward by Ni Made Gunastri (2009: 14) who said that "the nature and tasks that include responsibility, kinds of tasks and the level of satisfaction derived from the work itself. Works that are intrinsically rewarding to be more motivating for most people and the unsatisfactory work". 
Promotion (X2) implemented by the Public Works Department in East Java Province has a positive and significant impact on job satisfaction (Y1). This means the promotion in this case the experience (seniority), skills (skills) and the combination of experience and skills that are applied by the Public Works Department in East Java Province in accordance with the wishes and expectations of employees of the Public Works Department of Irrigation of East Java Province. Application of proper promotion system is one factor that can increase job satisfaction. The results of the study support the results of research conducted by Tambunan (2012), Minarsi (2007), Good (2011), Mariami (2013) and Nurjanati (2012) concluded that either simultaneously or partially promotions significant effect on employee job satisfaction. Then also supports the theory that says Hasibuan (2005: 113) says that "one of the objectives DARPI promotion is to give rise to satisfaction and personal pride, the higher the social status and income are increasingly BESA. Another implication is the management should encourage employees who are at the lowest level to make their own decisions and employees to believe in their job without having monitored every move she behaved. This is the principle of empowerment (empowerment) Employees ". From these statements it can be concluded that the direct implementation of the promotion is closely related to employee satisfaction and loyalty.

Discipline (X3) implemented by the Public Works Department in East Java Province has a positive and significant impact on job satisfaction (Y1). This means discipline in this case the purpose and capabilities, exemplary leadership, remuneration, fairness, penal sanctions, rigor and human relations that are applied by the Public Works Department in East Java Province in accordance with the wishes and expectations of employees of the Public Works Department in East Java Province, Discipline employees maximum will increase employee job satisfaction. The results of the study support the results of research conducted by Rohimah (2013) who said that disciplinary significant effect on satisfaction and discipline is the dominant variable affecting job satisfaction.

Characteristics of the work (X1) which is implemented by the Public Works Department in East Java Province has a positive and significant effect on loyalty work (Y2). This means that the characteristics of the work in this respect autonomy, variety of work, task identity, task significance and feedback is applied by the Public Works Department in East Java province in accordance with the wishes and expectations of employees of the Public Works Department in East Java Province. The level of job characteristics largely determine the suitability of employee loyalty. The results of the research fully supports the results of research conducted by Nugroho (2008) in his research to get the result that there is a significant direct effect between the characteristic of the work of the employee loyalty. The results of this study also supports the theory put forward by Steers and Porter (in Kusumo, 2006) states that the incidence of workplace loyalty is influenced by four factors: personal characteristics, job characteristics, the design characteristics of the company and the experience gained on the job.

Promotion (X2) implemented by the Public Works Department in East Java Province has a positive and significant effect on loyalty work (Y2). This means the promotion in this case the experience (seniority), skills (skills) and the combination of experience and skills that are applied by the Public Works Department in East Java Province in accordance with the wishes and expectations of employees of the Public Works Department of Irrigation of East Java Province. Application of proper promotion system is one factor that can increase the loyalty of work. The results support the results of research conducted by Mariami (2013) conclude that the study showed that motivation and career development indirect effect on loyalty employment through job satisfaction. It can be interpreted that the loyalty of employees will be increased significantly if the promotion is supported by employees' job satisfaction. The results 
of the present study also supports the theory put forward by Hasibuan (2005) said that "one of the factors that affect promotion is employee loyalty". From these statements it can be concluded that the direct implementation of the promotion is closely related to employee satisfaction and loyalty.

Discipline (X3) implemented by the Public Works Department in East Java Province has a positive and significant effect on loyalty work (Y2). This means discipline in this case the purpose and capabilities, exemplary leadership, remuneration, fairness, penal sanctions, rigor and human relations that are applied by the Public Works Department in East Java Province in accordance with the wishes and expectations of employees of the Public Works Department Irrigation East Java Province, Discipline employees maximum will increase employee loyalty. The results support the research conducted by Rohimah (2013) which states that there is a positive and significant influence between the variables of discipline against the employee loyalty.

Job satisfaction (Y1) are perceived by employees of the Public Works Department in East Java Province has a positive and significant effect on loyalty work (Y2). This means that job satisfaction in this challenging work, fair wages, working conditions that support and support from co-workers perceived employee influence employee loyalty Public Works Department of Irrigation of East Java Province. The results of this study support research done by Mariami (2013) that job satisfaction is positive and significant effect on employee loyalty. Theory advanced by Robbins (2002), which suggests that job satisfaction can be defined as a general attitude toward one's work, the difference between the amount of reward received by workers and the number that they believe should be accepted. Because a belief in the self-satisfied workers are more productive when compared with unsatisfied.

The results of this study indicate the direct and indirect influence of the variable characteristics of employment, promotion and working environments on job satisfaction and employee loyalty. Establishment of an intervening variable of job satisfaction in the analysis of the relationship between the characteristics of employment, promotion and working environment of the employees' loyalty. The third variable is the variable characteristic of latent employment, promotion and discipline directly affects employee loyalty or through any intervening through endogenous variable of job satisfaction.

\section{References}

Akinbobola, Akinyemi Olufunminiyi, Afolabi, Folashade. 2011. Analysis Science Process, Skills in West African Senior Secondary School Certificate Physics Practical Examination in Nigeria. Bulgarian Journal of Science and Education Policy (BJSEP), Volume 4, Number 1.

Arikunto, Suharsimi, 2010, Prosedur Penelitian, Penerbit Rineka Cipta, Jakarta.

Bagus, I Made, 2011, pengaruh antara karakteristik pekerjaan dan peluang promosi terhadap turnover Intentionn melalui kepuasan kerja dan komitmen karyawan Pada Hotel Bintang Empat di Surabaya, Jurnal Penelitian Mandiri No. DA/2011/Dosen Tetap Prodi Manajemen Fakultas Ekonomi Universitas PGRI Adi Buana Surabaya.

Bolino, M.C., Turnley, W.H., dan Bloodgood, J.M. (2002). Citizenship Behavior and the Creation of Social Capital in Organization. Academy of Management Journal, Vol. 7, No. 4, 2002 pp. 502-522.

Brown, Stephen P. 1996. A Meta-Analysis and Review of Organizational Research on Job Involvement Psychological Buletin.

Budiharjo, Kadarwati (2003). Metodologi dan Metode Penelitian Eksperimental. Yogyakarta: Koordinasi Perguruan Tinggi Swasta Wilayah V. 
Dipta Adi Prasetya dan Susilo Toto Rahardjo. 2012. Pengaruh Disiplin Kerja dan Budaya Organisasi Terhadap Kinerja Karyawan Pabrik Minyak Kayu Putih (PMKP) di Krai Purwodadi, Diponegoro Journal Of Management Volume 1, Nomor 1, Tahun 2012, Halaman 323-331, website http://ejournal-s1. Undip. ac. id/index.php/djom

Dollah, S.B. (1994). Penglihatan Pekerjaan Pegawai Sektor Awam: Satu kajian di Jabatan Kerja Raja Negeri Kaedah (Tesis). Universitas Utara Malaysia.

Emanuel, Ariek. (2011). “Analisis Pengaruh Kepuasan Kerja, Loyalitas Karyawan dan Perilaku Organisasi Terhadap Organizational Citizenship Behavior Serta Dampaknya Terhadap Efektifitas Organisasi Pada PT. Wirajaya Anugrah Perkasa”. Retrieved April 30, 2012. From source: http://eprints.binus.ac.id/6309/

Fahmi, Ilham, 2011, Manajemen Kinerja, CV. Alfabeta, Bandung

Gading. 1997. Kepuasan Kerja, Keterlibatan Kerja, Orientasi Nilai Terhadap Kerja dan Produktivitas Kerja Para Pekerja Wanita pada Sektor Informal di Kota Singaraja. Tesis.

Ghozali, Imam. 2013. Konsep dan Aplikasi Dengan Program Amos 21.0. Universitas Dipenogoro. Semarang

Greenberg, J. dan Baron, R. A. (2003). Manajemen Sumber Daya Manusia: Pengadaan, Pengembangan, Pengkompensasian, dan Peningkatan Produktivitas Pegawai. Grasindo, Jakarta.

Hadi, Sutrisno. 2001. Analisis Butir Untuk Instrumen Angket, Tes, dan Skala Nilai dengan BASICA. Edisi Pertama, cetakan pertama. Penerbit Andi Offset, Yogyakarta

Handoko, T. H. (2001). Manajemen Personalia dan Sumber Daya Manusia. Yogyakarta: BPFE

Handoko, T. Hani. 2012. Manajemen Personalia dan Sumber Daya Manusia. BPFE, Yogyakarta.

Hasibuan, M.S.P. (2001). Manajemen sumber daya manusia. (Edisi revisi) Jakarta: Bumi Aksara.

Hasibuan, S.P. Malayu, 2013, Manajemen Sumber Daya Manusia, PT. Bumi Aksara, Jakarta.

Hermawan, I Ketut Andy dan Gede Riana, 2012, Analisis Faktor-faktor Yang Menentukan Loyalitas Karyawan Pada PT. Inti Buana Permai Denpasar Bali, Jurnal Penelitian Mandiri Fakultas Ekonomi Universitas Udayana, Bali.

Hickling K. 2001. Job Statisfaction, Job Involvement, and Absenteeism: A Comparasion between Part-Time and Full-Time Retail Employee (Tesis) Universitas Adelaide.

Ina Inaturrohmah. 2010. Analisis Kemampuan dan Motivasi Serta Kepuasan Kerja Terhadap Kinerja Pegawai Negeri Sipil (Study Kasus Pada Kantor Camat Bunut Hilir Kabupaten Kapuas Hulu). Program Pascasarjana Terbuka, Jakarta.

Irawan, F. 2010. Riset Sumber Day Manusia : Cara Praktis Mengukur Stres, Kepuasan Kerja, Komitmen, Loyalitas, Motivasi Kerja dan Aspek-aspek Kerja Karyawan lainnya. Gramedia Pustaka Utama, Jakarta.

Jatmiko, Andrie, 2011, Pengaruh Karakteristrik Pekerjaan dan Budaya Kerja Terhadap Kepuasan Kerja Karyawan Pada Koperasi Nusantara Kantor Unit Soreang, Skripsi Fakultas Ekonomi Universitas Pasundan, Bandung.

Kanungo, R.N. 1982. Measurement of Job and Work Involvement. Journal of Applied Psychology.

Karia, N \& Asaari, MH.A.H. 2003. TQM Practices: Continuous Improvement and Problem Solving, International Bussiness Information Management 2003. Con ference. Cairo: Reffered Proceeding.

Kartiningsih. 2007. Analisis Pengaruh Budaya Organisasi dan Keterlibatan Kerja terhadap Komitmen Organisasi dalam meningkatkan Kinerja Karyawan (Study Kasus Pada PT. Bank Tabungan Negara (Persero) Cabang Semarang). Program Pascasarjana Universitas Diponegoro, Semarang.

Kusumo, B.C.S. (2006). Hubungan Antara Persepsi Terhadap Iklim Organisasi dan Kepuasan Imbalan Kerja Dengan Loyalitas Kerja Pada Karyawan. Surakarta: Fakultas Psikologi Universitas Muhammadiyah Surakarta.

Lodahl, T.M. \& Kejner M. 1985. The Definition and Measurement of Job Involvement. Journal Applied Psychology. Luthans, F. (2006). Perilaku Organisasi, Edisi Sepuluh. Yogyakarta: Andi.

Mangkunegara, A. A, Anwar Prabu, 2009, Evaluasi Kinerja Sumber Daya Manusia, Refika Aditama, Bandung. Mangkunegara, A. A, Anwar Prabu, 2011. Manajemen Sumber Daya Manusia Perusahaan, Remaja Rosdakarya, Bandung 
W, M. E. (2016). Role of Job Characteristics, Job Promotion and Disciplinary Work in Improving Employee Loyalty Through Job Satisfaction in Department of Public Work in East Java Province. Archives of Business Research, 4(2), 01-19.

Mangkunegara, A. P. (2005). Perilaku dan Budaya Organisasi, Cetakan Pertama. Bandung: PT. Refika Aditama.

Mariami, Ita, 2013, Pengaruh Motivasi Dan Pengembangan Karir Terhadap Loyalitas Kerja Karyawan Dengan Kepuasan Kerja Sebagai Variabel Intervening Pada Hotel Inna Dharma Deli Medan, Tesis, Program Pascasarjana Universitas Sumatera Utara, Medan

Mathis L. Robert-John H. Jackson. 2011. Human Resources Management 10th ed. Salemba Empat, Jakarta.

Minarsih, Maria Magdalena, 2007, Pengaruh Penghargaan, promosi jabatan dan Lingkungan Kerja Terhadap Kepuasan Kerja Karyawan di Universitas Pandanaran Semarang, urnal penelitian (http://jurnal.unimus.ac.id) Fakultas Ekonomi Universitas Pandanaran, Semarang.

Moynihan, DP \& Pandey SK. 2007. Finding Workable Levers over Work Motivation: Comparing Job Satisfaction, Job Involvement and Organizational Commitment. La Follette School Working Paper.

Nanggoy, S. \& Harianti, R. (2005). "Pengaruh Kepuasan Kerja Karyawan Terhadap Turnover Intentions di PT. Andalan Pacific Samudera di Surabaya” (Skripsi No.05011881/MAN/2005). Retrieved April 30, 2012. From source: http://dewey.petra.ac.id/dgt_res_detail.php?knokat=2626

Nugroho, Puguh Adi, 2008, Analisis Pengaruh Komitmen Organisasi Terhadap Loyalitas Karyawan Di Perusahaan PT. Garudafood Divisi Biskuit - gresik, Undergraduate Theses Airlangga University, Surabaya

Nurjanati, Fitriana, 2012, Tingkat Kepuasan Pegawai Eselon IV Atas Pelaksanaan Promosi Jabatan Pada Sekretariat Jenderal Kementrian Kehutanan, Skripsi, Fakultas Ilmu Sosial dan Ilmu Politik Departemen Ilmu Administrasi Program Sarjana Ekstensi, Depok.

Organ, D.W., et.al. (2006) Organizational Citizenship Behavior. Its Nature, Antecendents, and Consequences. California: Sage Publications, Inc.

Rivai, Veithzal, \& Ella Jauvani Sagala, 2011, Manajemen Sumber Daya Manusia untuk Perusahaan, Edisi kedua, Cetakan keempat, PT. Rajagrafindo Persada, Jakarta.

Robbins, P Stephen. 2003. Prinsip-prinsip Perilaku Organisasi. Edisi Kelima. Penerbit Erlangga, Jakarta.

Robbins, S. P. \& Judge, T.A. (2008). Perilaku Organisasi, Edisi Kedua Belas. Jakarta: Salemba Empat.

Robbins, S. P. (2003) Perilaku Organisasi: Konsep Kontroversi Aplikasi. Edisi Kedelapan. Trans. Pujaatmaka, H \& Molan, B. Jakarta: PT. Prenlindo.

Rohimah, Siti, 2013, Pengaruh Kompetensi, Kompensasi, Disiplin Kerja terhadap Kinerja dan Kepuasan Kerja Guru sma islamic village karawaci tangerang, Tesis, Progam Pascasarjana Universitas Esa Unggul, Jakarta

Roni Faslah. 2010. Hubungan Antara Keterlibatan Kerja Dengan Turnover Intention Pada Karyawan PT. Garda Trimitra Utama, Econo Sains Volume VIII No. 2 tahun 2010. Jakarta

Schein, Edgar H. 2009. The Corporate Culture Survival Guide. Jossey-Bass Publ. San Fransisco.

Sloat, K. C. M. (1999). Organizational Citizenship: Does Your Firm Inspire to be "good citizenship?" Professional Safety, Vol.44: 20-23.

Srivastava, SK. 2005. Organizational Behaviour and Management. Sarup \& Sons, New Delhi.

Sudarmanto, SIP, Msi. 2009. Kinerja dan Pengembangan Kompetensi SDM, Pustaka Pelajar, Yogyakarta

Sugiyono. 2006. Statistika Untuk Penelitian. Bandung: Penerbit CV. Alfabeta

Sutrisno, Edi, 2009. MSDM. Penerbit Kencana Prenada Media Group, Jakarta.

Tambunan, Junita Yanti, 2012, Pengaruh Lingkungan Kerja dan Promosi Jabatan Terhadap Kepuasan Kerja Pegawai Bagian Umum Sekretariat Daerah Kabupaten Tapanuli Tengah, Tesis, program Pascasarjana Universitas Terbuka, Jakarta

Tangkilisan, H.N.S., 2005, Manajemen Publik. Jakarta: Grasindo.

Thoha, Mifta, 2012, Perilaku Organisasi (Konsep Dasar dan Aplikasi), PT. Raja Grafindo Persada, Jakarta.

Torang, Samosir, 2013, Organisasi \& Manajemen (Perilaku, Struktur Budaya \& Perubahan Organisasi), CV. Alfabeta, Bandung 
Trianasari, Y. (2005). Hubungan Antara Persepsi Terhadap Insentif dan Lingkungan Kerja dengan Loyalitas Kerja. Surakarta: Fakultas Psikologi Universitas Muhammadiyah Surakarta.

Usmara, A. (2003). Paradigma Baru Manajemen Sumber Daya Manusia. Yogyakarta: Amara Books.

Utomo, B. (2002). Menentukan Faktor faktor Kepuasan Kerja dan Tingkat Pengaruh Kepuasan Kerja Terhadap Loyalitas Karyawan PT P. Jurnal Manajemen \& Kewirausahaan, Vol. 7 (2), 171-188.

Westhuizen, CVD. 2008. Work Related Attitude as Predictors of Employee Absenteeism. (Thesis). Universitas of South Africe.

Wibowo, 2010, Manajemen Kinerja. Edisi Ketiga, Penerbit Rajawali Pers,Jakarta.

Yaktiningsih A. 2006. Makna Bekerja: Studi tentang Makna Bekerja dan Hubungan antara Makna Bekerja dengan Keterlibatan Kerja pada Karyawan Perusahaan Industri Konstruksi dan Manufaktur Milik Negara. (Disertasi). Universitas Indonesia, Jakarta. 